\title{
Bank Lending and Interest- Rate Derivatives
}

\author{
Fang Zhao $^{1} \&$ James Moser ${ }^{2}$ \\ ${ }^{1}$ Department of Finance, Siena College, Loudonville, United States \\ ${ }^{2}$ Department of Finance and Real Estate, American University, Washington, DC, United States \\ Correspondence: Fang Zhao, Department of Finance, Siena College, Loudonville, NY 12211, United States.
}

Received: July 24, 2017

Accepted: August 15, 2017

Online Published: September 14, 2017

doi:10.5430/ijfr.v8n4p23

URL: https://doi.org/10.5430/ijfr.v8n4p23

\begin{abstract}
Using data that cover a full business cycle, this paper documents a direct relationship between interest-rate derivative usage by U.S. banks and growth in their commercial and industrial (C\&I) loan portfolios. This positive association holds for interest-rate options contracts, forward contracts, and futures contracts. This result is consistent with the implication of Diamond's model (1984) that predicts that a bank's use of derivatives permits better management of systematic risk exposure, thereby lowering the cost of delegated monitoring, and generates net benefits of intermediation services. The paper's sample consists of all FDIC-insured commercial banks between 1996 and 2004 having total assets greater than $\$ 300$ million and having a portfolio of C\&I loans. The main results remain after a robustness check.
\end{abstract}

Keywords: banking, derivatives, intermediation, swaps, futures, option, forward

\section{Introduction}

The relationship between the use of derivatives and lending activity has been documented in the literature. Brewer, Minton, and Moser (2000) evaluate an equation relating the determinants of Commercial and Industrial (C\&I) lending and the impact of derivatives on C\&I loan lending activity. They document a positive relationship between C\&I loan growth and the use of derivatives over a sample period from 1985 to 1992 . They find that the derivative markets allow banks to increase lending activities at a greater rate than the banks would have otherwise. Brewer, Jackson, and Moser (2001) examine the major differences in the financial characteristics of banking organizations that use derivatives relative to those that do not. They find that banks that use derivatives grow their business-loan portfolio faster than banks that do not use derivatives. Purnanandam (2007) also reports that the derivative users make more C\&I loans than non-users. There are two major research questions that arise in the literature: Does the use of derivatives facilitate loan growth? If not, is there a negative association between lending activity and derivative usage? Using recent data that cover a full business cycle, this study revisits these questions to ascertain whether a direct relationship still exists.

The sample in this study represents Federal Deposit Insurance Corporation (FDIC) insured commercial banks with total assets greater than $\$ 300$ million as of March 1996 that have a portfolio of C\&I loans. Following Brewer, Minton, and Moser (2000), we evaluate an equation relating the determinants of C\&I lending and the impact of derivatives on C\&I lending activity. The major finding in this study is that the interest-rate derivatives allow commercial banks to lessen their systematic exposure to changes in interest rates, which enables banks to increase their lending activities without increasing the total risk level faced by the banks. This consequently increases the banks' abilities to provide more intermediation services. Furthermore, a positive and significant association between lending and derivative activity indicates that the net effect of derivative use on C\&I lending is complementary. That is, the complementary effect dominates any substitution effect.

Additionally, this positive association holds for interest-rate options contracts, forward contracts, and futures contracts, suggesting that banks using any form of these contracts, on average, experience significantly higher growth in their C\&I loan portfolios. Furthermore, C\&I loan growth is positively related to capital ratio and negatively related to C\&I loan charge-offs. The findings in this study are confirmed after a robustness check.

Examining the relationship between the C\&I loan growth and derivative usage poses a potential endogeneity problem because the derivative-use decision and lending choices may be made simultaneously. To address this problem, an instrumental-variable approach is employed. Specifically, we estimate the probability that a bank will 
use derivatives in the first-stage specification, then we use the estimated probability of derivative usage as an instrument for derivative activity in the second-stage C\&I loan growth equation. A Hausman test indicates that the instrumental variable is a valid instrument. The probit specification for this instrumental variable is based on Kim and Koppenhaver (1992).

The remainder of this paper is organized as follows: The following section describes the sample and data sources. A discussion of the empirical specifications for commercial and industrial lending is provided in the third section. Next, the empirical results are presented in the fourth section. The fifth section provides robustness test results, and the final section concludes the paper.

\section{Data and Sample Description}

This section describes the sample selection criteria, the lending activity experience by FDIC-insured commercial banks from the first quarter of 1996 through the fourth quarter of 2004, as well as the interest-rate derivative products used by sample banks during the nine-year sample period.

\subsection{Sample Description}

The sample of banks includes FDIC-insured commercial banks with total assets greater than $\$ 300$ million as of March 1996. Of these institutions, banks that have no commercial and industrial loans are excluded. The sample ranges from 942 banks in March of 1996 to 467 banks in December of 2004. Institutions that are liquidated during the sample period are included in the sample before liquidation and excluded from the sample for the periods after liquidation. Banks that merge during the sample period are included in the sample. Balance sheet data and interest-rate derivative-usage information are obtained from the Reports of Condition and Income (Call Report) filed with the Federal Reserve System. State employment data are obtained from the U.S. Department of Labor, Bureau of Labor Statistics.

\subsection{Lending Activity}

Because the accessibility of credit depends importantly on banks' roles as financial intermediaries, loan growth is an important measure of intermediaries' activities. Following Brewer, Minton, and Moser (2000), we use C\&I loan growth as a measure of lending activity because such a measure performs a critical function in channeling funds between the financial and the productive sectors of the economy. Table 1 presents year-end data for bank C\&I loan lending activity for the sample banks from 1996 through 2004. The sample period covers a full business cycle and thereby provides a better indication of the relative variability of lending activities experienced by the commercial banks in different stages of a business cycle. Panels B through E report data for four categories of institutions classified by total asset size. Corresponding to the acceleration of C\&I loans in the late 1990s, the average ratio of C\&I loans to total assets increases steadily, from 12.44 percent at the year-end of 1997 to 13.15 percent at the year-end of 2000. Then, from year-end 2001 to year-end 2003, the average ratio of C\&I loans to total assets exhibits a downward trend, which corresponds to the economic recession beginning in March of 2001. As panels B through E report, this pattern exists across different sizes of banks, with the largest decline occurring for banks having total assets greater than $\$ 10$ billion. This decline stops at year-end 2004 when the overall economy experiences more rapid growth. 
Table 1. Lending activity based on year-end data beginning with 1996 through 2004 for FDIC-insured commercial banks with total assets greater than $\$ 300$ million

\begin{tabular}{|c|c|c|c|c|c|c|c|c|c|}
\hline & 1996 & 1997 & 1998 & 1999 & 2000 & 2001 & 2002 & 2003 & 2004 \\
\hline \multicolumn{10}{|l|}{ Panel A: All Banks } \\
\hline Average Total Assets (TA) & 3580.35 & 3993.56 & 4326.36 & 4503.84 & 4813.08 & 4823.37 & 4839.84 & 4908.20 & 5138.27 \\
\hline Average C\&I Loans /Total Assets & 0.1274 & 0.1244 & 0.1248 & 0.1281 & 0.1315 & 0.1224 & 0.1142 & 0.1102 & 0.1115 \\
\hline Number of Observation & 942 & 818 & 728 & 677 & 602 & 561 & 522 & 497 & 467 \\
\hline \multicolumn{10}{|l|}{ Panel B: Total Assets $<\$ 500$ million } \\
\hline Average Total Assets & 382.58 & 509.77 & 627.23 & 697.69 & 809.28 & 869.97 & 964.07 & 1004.05 & 1071.78 \\
\hline Average C\&I Loans /Total Assets & 0.1120 & 0.1081 & 0.1077 & 0.1106 & 0.1107 & 0.1075 & 0.1008 & 0.0965 & 0.0967 \\
\hline Number of Observations & 366 & 334 & 299 & 271 & 247 & 228 & 213 & 207 & 197 \\
\hline \multicolumn{10}{|c|}{$\begin{array}{l}\text { Panel C: } \$ 500 \text { million } \leq \text { Total Assets }<\$ 1 \\
\text { billion }\end{array}$} \\
\hline Average Total Assets & 685.24 & 871.85 & 1083.70 & 1231.14 & 1436.22 & 1608.72 & 1817.49 & 2062.01 & 2322.21 \\
\hline Average C\&I Loans / Total Assets & 0.1139 & 0.1107 & 0.1105 & 0.1129 & 0.1235 & 0.1130 & 0.1095 & 0.1093 & 0.1122 \\
\hline Number of Observations & 232 & 208 & 185 & 176 & 155 & 146 & 135 & 134 & 129 \\
\hline \multicolumn{10}{|c|}{$\begin{array}{l}\text { Panel D: } \$ 1 \text { billion } \leq \text { Total Assets }<\$ 10 \\
\text { billion }\end{array}$} \\
\hline Average Total Assets & 3059.11 & 4290.94 & 5163.10 & 5956.50 & 7310.57 & 9056.01 & 1020.88 & 11613.84 & 12936.69 \\
\hline Average C\&I Loans /Total Assets & 0.1425 & 0.1463 & 0.1459 & 0.1491 & 0.1529 & 0.1411 & 0.1304 & 0.1273 & 0.1309 \\
\hline Number of Observations & 281 & 226 & 198 & 186 & 159 & 151 & 140 & 122 & 108 \\
\hline \multicolumn{10}{|l|}{ Panel E: Total Assets $\geq \$ 10$ billion } \\
\hline Average Total Assets & 3197.43 & 5671.76 & 6765.21 & 7378.67 & 8633.30 & 9802.80 & 1127.43 & 123901.87 & 142795.34 \\
\hline Average C\&I Loans / Total Assets & 0.1982 & 0.1916 & 0.2022 & 0.2079 & 0.2036 & 0.1766 & 0.1504 & 0.1361 & 0.1332 \\
\hline Number of Observations & 63 & 50 & 46 & 44 & 41 & 36 & 34 & 34 & 33 \\
\hline
\end{tabular}

\subsection{Interest-rate Derivative Products}

The use of interest-rate derivatives by banks has grown dramatically in recent years, rising from notional amounts of $\$ 27.88$ trillion at the end of 1996 to $\$ 62.78$ trillion at the end of 2004 . Four main categories of interest-rate derivative instruments are examined: swaps, options, forwards, and futures. Table 2 presents the frequency of use of each type of interest-rate derivative by banks from year-end 1996 through year-end 2004. As in Table 1, data are reported for the entire sample of banks and for four subgroups of banks categorized by total asset size. Table 2 shows extensive participation of banks in the interest-rate derivative markets over the nine-year sample period. Furthermore, the rapid growth in the use of various types of derivative instruments has not been confined to large commercial banks; medium-size and small-size banks have also experienced a tremendous increase in the participation of derivative markets.

As shown in Table 2, during the entire sample period, the most widely used interest-rate derivative instrument is the swap. At the end of 1996, 31.6 percent of banks report using interest-rate swaps. By the end of 2004, the percentage using swaps rise to 37.3 percent. Over the nine-year sample period, more than 95 percent of banks with total assets exceeding \$10 billion report using interest-rate swaps. 
Table 2. The use of derivatives based on year-end data beginning with 1996 through 2004 for FDIC-insured commercial banks with total assets greater than $\$ 300$ million

\begin{tabular}{|c|c|c|c|c|c|c|c|c|c|}
\hline & 1996 & 1997 & 1998 & 1999 & 2000 & 2001 & 2002 & 2003 & 2004 \\
\hline \multicolumn{10}{|l|}{ Panel A: All Banks } \\
\hline Users of Swaps (\%) & 31.57 & 35.08 & 34.47 & 34.27 & 32.72 & 31.86 & 33.14 & 39.03 & 37.26 \\
\hline Average Ratio to Total Assets a & 0.3084 & 0.3341 & 0.4316 & 0.4542 & 0.5307 & 0.4822 & 0.4982 & 0.5636 & 0.5812 \\
\hline Users of Options (\%) & 16.45 & 19.19 & 19.64 & 19.79 & 19.60 & 16.22 & 15.52 & 14.08 & 13.49 \\
\hline Average Ratio to Total Assets ${ }^{b}$ & 0.1066 & 0.1058 & 0.1426 & 0.1471 & 0.1412 & 0.1312 & 0.1520 & 0.2197 & 0.2232 \\
\hline Users of Forwards (\%) & 9.02 & 12.22 & 11.13 & 11.82 & 11.63 & 13.19 & 16.48 & 19.32 & 22.06 \\
\hline Average Ratio to Total Assets ${ }^{c}$ & 0.1926 & 0.1342 & 0.2017 & 0.1584 & 0.1598 & 0.1502 & 0.1552 & 0.0931 & 0.0717 \\
\hline Users of Futures (\%) & 5.28 & 5.13 & 5.36 & 5.47 & 4.65 & 5.53 & 5.75 & 6.24 & 6.85 \\
\hline Average Ratio to Total Assets ${ }^{d}$ & 0.4291 & 0.3288 & 0.4283 & 0.2965 & 0.3225 & 0.4598 & 0.3854 & 0.4022 & 0.2151 \\
\hline $\begin{array}{l}\text { Users of swaps, options, forwards, and futures } \\
(\%)\end{array}$ & 3.18 & 3.42 & 3.02 & 3.40 & 2.99 & 3.92 & 4.02 & 4.02 & 4.28 \\
\hline Number of Observations & 942 & 818 & 728 & 677 & 602 & 561 & 522 & 497 & 467 \\
\hline \multicolumn{10}{|l|}{ Panel B: Total Assets $<\mathbf{\$ 5 0 0}$ million } \\
\hline Users of Swaps (\%) & 7.38 & 7.78 & 8.02 & 10.32 & 8.91 & 7.02 & 10.80 & 13.53 & 15.23 \\
\hline Average Ratio to Total Assets ${ }^{a}$ & 0.1238 & 0.0945 & 0.0778 & 0.1020 & 0.0540 & 0.0618 & 0.0740 & 0.0726 & 0.0620 \\
\hline Users of Options (\%) & 2.73 & 3.89 & 4.35 & 4.80 & 4.45 & 5.26 & 2.35 & 2.46 & 1.52 \\
\hline Average Ratio to Total Assets ${ }^{b}$ & 0.0952 & 0.0967 & 0.0885 & 0.0972 & 0.0972 & 0.0932 & 0.0313 & 0.0248 & 0.0165 \\
\hline Users of Forwards (\%) & 0.43 & 1.50 & 1.34 & 1.85 & 2.43 & 3.51 & 10.37 & 10.14 & 11.17 \\
\hline Average Ratio to Total Assets ${ }^{c}$ & 0.0270 & 0.010 & 0.0288 & 0.0175 & 0.0147 & 0.0412 & 0.0565 & 0.0124 & 0.0096 \\
\hline Users of Futures (\%) & 0.55 & 0.30 & 0.00 & 0.00 & 0.00 & 0.44 & 0.47 & 0.97 & 1.02 \\
\hline Average Ratio to Total Assets ${ }^{d}$ & 0.3739 & 0.0505 & 0.00 & 0.00 & 0.00 & 0.0333 & 0.0352 & 0.0383 & 0.0384 \\
\hline $\begin{array}{l}\text { Users of swaps, options, forwards, and futures } \\
(\%)\end{array}$ & 0.00 & 0.00 & 0.00 & 0.00 & 0.00 & 0.00 & 0.00 & 0.00 & 0.00 \\
\hline Number of Observations & 366 & 334 & 299 & 271 & 247 & 228 & 213 & 207 & 197 \\
\hline \multicolumn{10}{|l|}{$\begin{array}{l}\text { Panel C: } \mathbf{5 5 0 0} \text { million } \leq \text { Total Assets }<\mathbf{S 1} \\
\text { billion }\end{array}$} \\
\hline Users of Swaps (\%) & 19.39 & 18.27 & 19.45 & 21.02 & 18.71 & 17.81 & 22.96 & 29.10 & 31.00 \\
\hline Average Ratio to Total Assets ${ }^{a}$ & 0.1327 & 0.1007 & 0.0521 & 0.0610 & 0.0729 & 0.0661 & 0.0469 & 0.0495 & 0.0621 \\
\hline Users of Options (\%) & 7.33 & 9.62 & 11.35 & 10.23 & 11.61 & 5.48 & 3.86 & 3.73 & 3.88 \\
\hline Average Ratio to Total Assets ${ }^{b}$ & 0.0731 & 0.0624 & 0.0807 & 0.0972 & 0.0513 & 0.0304 & 0.0687 & 0.1480 & 0.1480 \\
\hline Users of Forwards (\%) & 1.42 & 6.73 & 5.95 & 3.98 & 5.81 & 8.22 & 13.33 & 16.42 & 22.48 \\
\hline Average Ratio to Total Assets ${ }^{c}$ & 0.0160 & 0.0190 & 0.0391 & 0.0296 & 0.0296 & 0.0558 & 0.0581 & 0.0306 & 0.0240 \\
\hline Users of Futures (\%) & 0.00 & 0.48 & 0.67 & 1.14 & 1.29 & 2.05 & 1.48 & 1.49 & 2.33 \\
\hline Average Ratio to Total Assets ${ }^{d}$ & 0.00 & 0.0201 & 0.0057 & 0.0302 & 0.0301 & 0.0308 & 0.0508 & 0.0707 & 0.0247 \\
\hline $\begin{array}{l}\text { Users of swaps, options, forwards, and futures } \\
(\%)\end{array}$ & 0.00 & 0.00 & 0.00 & 0.00 & 0.00 & 0.00 & 0.74 & 0.75 & 1.55 \\
\hline Number of Observations & 232 & 208 & 185 & 176 & 155 & 146 & 135 & 134 & 129 \\
\hline
\end{tabular}

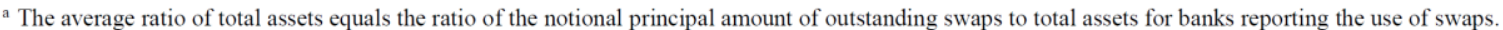

${ }^{\mathrm{b}}$ The average ratio of total assets equals the ratio of the notional principal amount of outstanding options to total assets for banks reporting the use of options.

c The average ratio of total assets equals the ratio of the notional principal amount of outstanding forwards to total assets for banks reporting the use of forwards

d The average ratio of total assets equals the ratio of the notional principal amount of outstanding futures to total assets for banks reporting the use of futures.

Table 2 (Continued). The use of derivatives based on year-end data beginning with 1996 through 2004 for FDIC-insured commercial banks with total assets greater than $\$ 300$ million

\begin{tabular}{|c|c|c|c|c|c|c|c|c|c|}
\hline & 1996 & 1997 & 1998 & 1999 & 2000 & 2001 & 2002 & 2003 & 2004 \\
\hline \multicolumn{10}{|l|}{ Panel D: $\$ 1$ billion $\leq$ Total Assets $<\$ 10$ billion } \\
\hline Users of Swaps (\%) & 56.58 & 53.09 & 57.57 & 65.59 & 65.41 & 57.62 & 60.00 & 62.29 & 65.74 \\
\hline Average Ratio to Total Assets ${ }^{\text {a }}$ & 0.1226 & 0.1245 & 0.1151 & 0.1037 & 0.0821 & 0.0991 & 0.0969 & 0.0990 & 0.1158 \\
\hline Users of Options (\%) & 25.62 & 34.51 & 33.84 & 33.87 & 35.22 & 25.83 & 26.43 & 24.59 & 22.22 \\
\hline Average Ratio to Total Assets ${ }^{\mathrm{b}}$ & 0.0620 & 0.0460 & 0.0503 & 0.0602 & 0.0594 & 0.0685 & 0.0460 & 0.0641 & 0.1062 \\
\hline Users of Forwards (\%) & 13.52 & 19.47 & 17.68 & 19.89 & 18.24 & 19.21 & 20.00 & 24.59 & 27.78 \\
\hline Average Ratio to Total Assets ${ }^{c}$ & 0.0290 & 0.0194 & 0.0468 & 0.0178 & 0.0199 & 0.0712 & 0.0753 & 0.0341 & 0.0536 \\
\hline Users of Futures (\%) & 5.69 & 6.19 & 7.03 & 6.99 & 5.66 & 5.96 & 6.43 & 7.38 & 7.41 \\
\hline Average Ratio to Total Assets ${ }^{d}$ & 0.3500 & 0.2220 & 0.1831 & 0.1352 & 0.0673 & 0.1044 & 0.1086 & 0.0909 & 0.0217 \\
\hline Number of Observations & 281 & 226 & 198 & 186 & 159 & 151 & 140 & 122 & 108 \\
\hline \multicolumn{10}{|l|}{ Panel E: Total Assets $\geq \$ 10$ billion } \\
\hline Users of Swaps (\%) & 96.82 & 100 & 100 & 100 & 100 & 100 & 100 & 100 & 100 \\
\hline Average Ratio to Total Assets ${ }^{\text {a }}$ & 0.9196 & 1.1207 & 1.6920 & 1.7834 & 1.9616 & 2.3357 & 2.0354 & 2.6250 & 2.570 \\
\hline Users of Options (\%) & 88.89 & 92.00 & 91.30 & 90.91 & 87.80 & 88.89 & 91.18 & 91.18 & 93.94 \\
\hline Average Ratio to Total Assets ${ }^{\mathrm{b}}$ & 0.1762 & 0.2285 & 0.3375 & 0.3433 & 0.3294 & 0.2610 & 0.3196 & 0.3889 & 0.3460 \\
\hline Users of Forwards (\%) & 66.67 & 74.00 & 67.39 & 70.45 & 63.41 & 69.44 & 76.47 & 67.65 & 66.67 \\
\hline Average Ratio to Total Assets ${ }^{c}$ & 0.3614 & 0.3313 & 0.4568 & 0.3780 & 0.3945 & 0.3221 & 0.3617 & 0.3033 & 0.2215 \\
\hline Users of swaps, options, forwards, and futures (\%) & 38.10 & 44.00 & 41.30 & 38.64 & 34.15 & 44.44 & 47.06 & 47.06 & 45.5 \\
\hline Number of Observations & 63 & 50 & 46 & 44 & 41 & 36 & 34 & 34 & 33 \\
\hline
\end{tabular}

${ }^{a}$ The average ratio of total assets equals the ratio of the notional principal amount of outstanding swaps to total assets for banks reporting the use of swaps.

${ }^{\mathrm{b}}$ The average ratio of total assets equals the ratio of the notional principal amount of outstanding options to total assets for banks reporting the use of options.

${ }^{c}$ The average ratio of total assets equals the ratio of the notional principal amount of outstanding forwards to total assets for banks reporting the use of forwards.

${ }^{\mathrm{d}}$ The average ratio of total assets equals the ratio of the notional principal amount of outstanding futures to total assets for banks reporting the use of futures 
Another notable increase occurred in the forward-rate agreement (FRA) usage. FRA is a contract that determines the rate of interest, or currency exchange rate, to be paid or received on an obligation beginning at some future date. At the end of 1996, 9.02 percent of the sample banks report using FRAs. By the end of 2004, the percentage using FRAs more than doubled. While the percentage of banks participating in the swaps and forwards increased over the sample period, the proportion of banks using interest-rate options fell. This decline is most notable between year-end 2000 and year-end 2004. With the exception of banks with total assets greater than $\$ 10$ billion, less than 7.5 percent of banks report having open positions in interest-rate futures.

Finally, less than 3 percent of the sample banks report having open positions in interest-rate swaps, interest-rate options, interest-rate forwards, and interest-rate futures. In contrast, nearly half of the banks with total assets greater than $\$ 10$ billion report having positions in all four types of interest-rate derivative instruments. This result strongly suggests that large banking organizations are much more likely than small banking organization to use derivatives. As shown in Panel E of Table 2, approximately 25 of the largest banks heavily participated in the interest-rate derivative market, a result similar to the finding of Carter and Sinkey (1998).

\section{Specifications of Variables}

Based on the literature regarding the determinants of bank lending, this section describes the specification for intermediation, the independent variables used in the empirical model, and the measure of derivative activities.

\subsection{The Specification for Intermediation}

The foundation of the empirical analysis in this article is the specification for bank lending by Sharpe and Acharya (1992). They regress a measure of lending activity on a set of possible supply and demand factors $\left(X_{j, t-1}\right)$. Brewer, Minton, and Moser (2000), who studied an earlier sample of commercial banks for the period June 30, 1985, through the end of 1992, extended the specification by adding a measure of participation in interest-rate derivative markets $\left(D E R I V_{j, t}\right.$ ) into the equation. Following Sharpe and Acharya (1992), we use the quarterly change in C\&I loans relative to last period's total assets $\left(C I L G A_{j, t}\right)$ as the dependent variable. In order to examine the relationship between the growth in bank C\&I loans and the banks' participation in interest-rate derivative markets, we also include various measures of participation in interest-rate derivative markets $\left(D E R I V_{j, t}\right)$ in the following regression specification:

$$
C I L G A_{j, t}=f\left(X_{j, t-1}, D E R I V_{j, t}\right)
$$

\subsection{Independent Variables (Traditional Supply and Demand Factors)}

The explanatory variables represent both supply and demand factors $\left(X_{j, t-1}\right)$. Based on the literature on the determinants of bank lending, we determine how these supply and demand factors enter into the regression specification. First, Bernanke and Lown (1991) and Sharpe and Acharya (1992) relate overall loan growth to capital requirements. In addition, Sharpe (1995) finds that there is a positive association between bank capital and loan growth. Beatty and Gron (2001) document that, consistent with Sharpe's finding, banks with higher capital growth relative to assets experience greater increases in their loan portfolios, and banks with weak capital positions are less able to increase their loan portfolios due to capital constraints. When a bank's capital falls short of the required amount, the bank could attempt to raise the capital-to-asset ratio by reducing its assets (the denominator of the ratio) rather than raising capital (the numerator of the ratio). One way of doing this is to shift the asset portfolio away from lending, such as cutting back its investment in C\&I loans. Banks may choose this strategy over equity issuance simply because issuing equity is costly. Therefore, undercapitalized banks are less able to increase their loan 
portfolios while satisfying the regulatory capital requirements. In contrast, banks with stronger capital positions have more room to expand their loan portfolios and still be able to satisfy the regulatory requirement for the capital-to-asset ratio. If capital-constrained banks adjust their lending to meet some predetermined target capital-to-asset ratios, one would expect a positive relationship between a bank's capital-to-asset ratio and C\&I loan growth. In order to control for the effect of capital requirements on C\&I lending activity, a measure of the bank's capital-to-asset ratio (CARATIO) is included in the empirical specification for C\&I loan growth. CARATIO is measured as the ratio of a bank's total equity capital to total assets at time t-1.

Another factor found to affect loan growth is the quality of a bank's loan portfolio. Following Sharpe and Acharya (1992), we use C\&I loan charge-offs (CILCOFA) as a proxy for loan quality. Another measure of loan quality is the provision for loan losses. The reason that charge-offs is used instead of provision for loan losses is because the loan charge-offs variable also captures the impact of regulatory influence. The variable CILCOFA is constructed as the ratio of C\&I loan charge-offs in the last period (t-1) to total assets in the last period (t-1). Charge-offs usually rise during a recession and decline only after an economic recovery. Therefore, a low charge-offs ratio can also be a signal of a favorable economic environment in a bank's geographic region of operations. In addition, the ratio of C\&I loan charge-offs to total assets could capture the impact of regulatory pressures on loan growth because regulators often apply pressure to banks to increase their rates of charge-offs. For example, capital-constrained banks may be required to increase their rates of charge-offs so that they can clear the regulatory hurdle for capital ratios by eliminating some of their assets. Therefore, the ratio of C\&I loan charge-offs to total assets could reflect the impact of regulatory pressures on banks' capital management. Each of these reasons suggests that those banks with high charge-offs should, other things being equal, be viewed as less well capitalized than banks with low charge-offs, and are therefore less able to increase their loan portfolios due to capital constraints. For these reasons, one would expect CILCOFA to have a negative association with C\&I loan growth.

The relationship between bank health and regional economic conditions is another factor to consider. The idea that regional economic performance affects bank health is intuitive and broadly consistent with the aggregate banking data. Avery and Gordy (1998) find that one-half of the change in bank loan performance from 1984 to 1995 can be explained with a group of state-level economic variables. Also, Bernanke and Lown (1991) and Williams-Stanton (1996) point out that regional economic conditions should influence bank C\&I loan growth. The intuition is that banks in states with weak economic conditions are likely to have fewer profitable opportunities than banks in states with stronger economies. The state employment growth rate $\left(E M P G_{j, t-1}\right)$ is included in the model as a proxy for local economic conditions that are not captured by the other explanatory variables. If state employment growth is a proxy for economic conditions, one would expect EMPG to be positively related to C\&I loan growth, other things being equal.

\subsection{Measure of Derivative Activities}

In order to capture the effects of derivative usage on bank-loan growth, we include various measures of participation in interest-rate derivative markets ( $D E R I V_{j, t}$ ) in the C\&I loan growth specification (the construction of this variable is presented in equation 2). DERIV is a binary variable equals to one if a bank engages in any interest-rate derivative activity, zero otherwise. The coefficient estimate on DERIV reflects the impact of derivative usage conditional on adequately incorporating the intermediating process in the remaining terms of the specification. Modern theories of the intermediary role of banks describe how derivative contracting and lending can be complementary activities. Diamond (1984) develops a theory of financial intermediation. In his model, banks optimally offer debt contracts to "depositors" and accept debt contracts from "entrepreneurs." Depositors delegate monitoring activities to banks that have the ability to economize the costs of monitoring loan contracts made with entrepreneurs. However, banks face an incentive problem that originates from the cost of delegated monitoring on behalf of their depositors. Diamond 
shows that diversification within a bank lowers the cost of delegated monitoring. An implication of his model is that banks should not assume any nondiversifiable risks unless they have special advantages in managing them. Thus in his model, banks find it optimal to hedge all interest-rate risk by interest-rate derivatives. However, even after diversifying, banks may still face systematic risks that cannot be diversified away.

Diamond demonstrates that derivative contracts can serve as a third form of contracting, which enables banks to reduce their exposure to systematic risk in their loan portfolios. This use of derivative contracts to hedge systematic risks enables banks to obtain further reductions in delegation costs, and, in turn, allows banks to intermediate more effectively. If interest-rate derivative activity complements the lending activity as predicted by Diamond's (1984) model, one would expect a positive coefficient estimate on the DERIV variable.

In this study, a downward trend in C\&I lending during the economic recession beginning in March of 2001 is observed. Brewer, Minton, and Moser (2000) also document a similar pattern regarding C\&I lending over a sample period from 1985 to 1992, a period during which the economy experienced a significant cyclical downturn. They argue that the downward trend in lending activity and the concurrent increase in the use of interest-rate derivatives suggest that derivative usage might be a substitute for lending activity. They suggest that a negative relationship between derivative usage and lending activity could arise in two cases. The first case is when banks use derivatives for speculative purposes. Gain from speculating on interest-rate changes would enhance revenues from bank trading desks. The second instance is when banks charge a fee as over-the-counter dealers for placing derivative positions. Pursuit of either of these activities as a replacement for the traditional lending activities of banks would imply that derivative activity would be a substitute for lending activity. If these activities were substitutes, one would expect a negative coefficient on the DERIV variable. From the above discussion, a specification for Equation (2) can be written as follows:

$$
\begin{aligned}
\text { CILGA }_{j, t}= & \alpha_{0}+\sum_{t=2}^{T} \alpha_{t} D_{t}+\beta_{1} \text { CARATIO }_{j, t-1}+\beta_{2} \text { CILCOFA }_{j, t-1} \\
& +\beta_{3} \text { EMPG }_{j, t-1}+\beta_{4} \text { DERIV }_{j, t}+\varepsilon_{j, t}
\end{aligned}
$$

In Equation (2), $C I L G A_{j, t}$ is measured as the quarterly change in C\&I loans relative to last period's total assets.

$D_{t}$ is a time-indicator variable equal to one for period $\mathrm{t}$, or zero otherwise. The variable $C A R A T I O_{j, t-1}$ is the ratio of a bank's total equity capital to total assets in the previous period (t-1). CILCOFA $A_{j, t-1}$ is the ratio of C\&I loan charge-offs in the previous period ( $\mathrm{t}-1)$ to total assets in the previous period (t-1). $E M P G_{j, t-1}$ is the state employment growth rate relative to last period (t-1), where EMP equals total employment in the state in which the bank's headquarters are located. The variable $D E R I V_{j, t}$ is a measure of participation in interest-rate derivative markets.

Table 3 reports summary statistics for the variables used in the estimation of Equation (2). The mean of quarter-to-quarter changes in C\&I loans scaled by values of beginning-of-quarter total assets is 0.4 percent over the full sample period. During this period, the average capital-to-asset ratio is 9.45 percent, the average C\&I loan charge-offs over assets is 0.05 percent, and the average state employment growth rate is 0.45 percent. Consistent with the data presented in Table 2, 20.78 percent of the sample banks reported using interest-rate swaps during the sample period, 11.26 percent of the sample banks reported using interest-rate options, and 8.61 percent reported using FRAs. Only 3.28 percent of the sample banks reported using interest-rate futures. Finally, over-the-counter dealers and subsidiaries of foreign banks comprise only 1.2 percent and 4.5 percent, respectively, of the sample bank observations. 
Table 3. Summary statistics for the full sample ${ }^{a}$

\begin{tabular}{|c|c|c|c|c|}
\hline Variable & Mnemonic & Mean & $\begin{array}{l}\text { Standard } \\
\text { Deviation }\end{array}$ & Observations \\
\hline \multicolumn{5}{|c|}{ Dependent variable and supply and demand factors } \\
\hline \multicolumn{5}{|l|}{ Dependent variable } \\
\hline C\&I Loan Growth over total assets & CILGA & 0.004 & 0.0525 & 293568 \\
\hline \multicolumn{5}{|l|}{ Supply and demand factors } \\
\hline Capital to asset ratio & CARATIO & 0.0945 & 0.0460 & 248278 \\
\hline C\&I loan charge-offs over assets & CILCOFA & 0.0005 & 0.0012 & 232234 \\
\hline Employment growth & EMPG & 0.0043 & 0.0727 & 248277 \\
\hline Log total assets & LNTOTASST & 13.75 & 1.2323 & 293536 \\
\hline \multicolumn{5}{|c|}{ Additional supply and demand factors used in robustness tests } \\
\hline Lagged dependent variable & Defined Above & & & \\
\hline Unused credit lines to total assets & UNLC & 0.0092 & 0.0233 & 224571 \\
\hline \multicolumn{5}{|l|}{ Classification Variable } \\
\hline Swaps $(0-Y e s, 1-\mathrm{No})$ & DSWAP & 0.2078 & 0.4057 & 294475 \\
\hline Futures $(0-\mathrm{Yes}, 1-\mathrm{No})$ & DFUTURES & 0.0328 & 0.1782 & 294475 \\
\hline Forwards $(0-\mathrm{Yes}, 1-\mathrm{No})$ & DFORWARD & 0.0861 & 0.2805 & 294475 \\
\hline Options (0-Yes, 1-No) & DOPTION & 0.1126 & 0.3161 & 294475 \\
\hline Derivatives Dealer (0-No, 1-Yes) & DEALER & 0.0120 & 0.1082 & 294475 \\
\hline Foreign Bank (0-No, 1-Yes) & FBANK & 0.0453 & 0.2081 & 294475 \\
\hline
\end{tabular}

${ }^{a}$ Means and standard deviations for all variables are used in the empirical analyses. The statistics are computed over the period from March 1996 through December 2004.

\subsection{Instrumental Variable}

Examining the relationship between the C\&I loan growth and derivative usage poses a potential endogeneity problem because the derivative-use decision and lending choices may be made simultaneously. As the data show, the decisions could be made jointly since a bank's C\&I lending activity might affect its decision to use derivatives. The estimation by the Ordinary Least Squares (OLS), in this case, would yield biased results. To address this problem, an instrumental-variable approach is used. Specifically, we carry out the Hausman test to check the existence of endogeneity and afterwards we use instrumental variables to estimate the effect of derivative usage on C\&I loan growth. In the probit model, DERIV is used as dependent variable. The probit specification for the instrumental variable is based on Kim and Koppenhaver (1992). This probit specification includes the log of bank assets, the capital-to-asset ratio, net interest margin, and the first lag of the dependent variable. Commercial bank size as measured by the logarithm of its total assets is included to control for the differences in derivative use that might be caused by differences in the types of businesses and customers at large and small banks. The capital-to-asset ratio is included in the probit specification because a bank's capital adequacy is a necessary condition for its participation in the derivative market. A bank's net interest margin enters into the equation because banks can use derivatives to lock-in the spread between interest income and interest expense. Since derivative use at time $t$ is usually dependent on derivative use at time $\mathrm{t}-1$, the first lag of the dependent variable is included to take into account the dependence over time. To determine the probability of a bank's derivative usage, the above probit specification for each sample date $t$ is estimated, and then the estimated probability from the first-stage estimation is used as an instrument for derivative activity in the second-stage estimation. A Hausman test indicates that the instrumental variable is a valid instrument. The results of this first-stage regression are presented in Appendix A. Overall, the probit results show that, as predicted, bank size, capital-to-asset ratio, and the lagged dependent variable play a significant role in determining the probability of derivative usage by U.S. commercial banks.

Since banks' use of derivatives increases during the sample period, a pooled cross-sectional time-series regression is employed to incorporate this dynamic effect. A Hausman test indicates that the instrumental variable is a valid instrument. Appendix B provides the coefficient on the time-period indication variables. Specifically, we run a cross-sectional Ordinary Least Squares regression with C\&I loan growth as the dependent variable and then report the time-series means of the parameter estimates and their corresponding t-statistics. The $t$-values are computed using Newey-West heteroskedasticity-and-autocorrelation-consistent errors. We use the predicted derivative use, obtained from the probit specification, to instrument the actual derivative-use variable as an independent variable. 


\section{Empirical Results}

Using the quarterly change in C\&I loans relative to last period's total assets as the dependent variable, we utilize Equation (2) to examine the determinants of C\&I lending and the impact of derivatives on C\&I lending activity. Table 4 reports the results of pooled cross-sectional time-series regressions using quarterly data from March 1996 through December 2004.

Regression (1) of Table 4 is the reduced form of the supply equation that examines the impact of fundamental factors on C\&I lending activity. This regression serves as a base for examining the relationship between derivative activity and $C \& I$ lending. In regression (1), C\&I loan growth is significantly and positively related to the beginning-of-period CARATIO. This result is consistent with the hypothesis that capital-constrained banks adjust their loan portfolios in subsequent periods to meet some predetermined target capital-to-asset ratios. Similar to Brewer, Minton, and Moser (2000), we also find a significant, negative association between CILCOFA and C\&I loan growth. This negative relationship is consistent with the notion that the charge-offs variable captures the impact of regulatory pressures, a strong economic environment, or both. The previous period's state employment growth variable EMPG fails to enter the equation significantly. This result is inconsistent with Brewer, Minton, and Moser (2000), who study a sample of banks that predates the advent of interstate banking. During the course of the 1990s, deregulation in the banking industry led to consolidation and to banks' geographic expansion. As a result, U.S. banks have also become more geographically diversified. In fact, the regression results might suggest that state economies play a lesser role in affecting banks' health and performance following the full expansion of interstate banking.

Regressions (2) and (3) include different measures of derivative activity. Regression (2) augments the predicted probability of derivative usage in any type of interest-rate derivative contract (DERIV). Regression (3) decomposes the DERIV variable into four types of interest-rate derivative instruments: SWAPS, OPTIONS, FORWARDS, and FUTURES. Each type of derivative activity is estimated using the probit specification discussed earlier in this section. The estimates generated in the probit specification are then used in conjunction with the supply and demand factors in the second-stage regression to predict C\&I loan growth.

Columns (2) and (3) of Table 4 report the estimation results for the derivative-augmented regressions. First, the coefficient estimates on CARATIO, CILCOFA, and EMPG are qualitatively similar to those in the base model. Second, the CARATIO and CILCOFA coefficient estimates remain statistically significant. 
Table 4. Univariate multiple regression coefficient estimates for the determinants of quarterly changes in C\&I loans relative to last period's total assets ${ }^{\mathrm{a}, \mathrm{b}}$

\begin{tabular}{|c|c|c|c|c|}
\hline Independent variables & Regression (1) & Regression (2) & Regression (3) & Regression (4) \\
\hline CARATIO & $\begin{array}{c}0.1037 \\
(3.48)^{\star \star \star}\end{array}$ & $\begin{array}{c}0.1041 \\
(3.47)^{\star \star \star}\end{array}$ & $\begin{array}{c}0.1042 \\
(3.47)^{\star \star \star}\end{array}$ & $\begin{array}{c}0.0791 \\
(2.16)^{\star \star}\end{array}$ \\
\hline CILCOFA & $\begin{array}{c}-0.8336 \\
(-3.65)^{\star \star \star}\end{array}$ & $\begin{array}{c}-0.8569 \\
(-3.77)^{\star \star \star}\end{array}$ & $\begin{array}{c}-0.8603 \\
(-3.79)^{\star \star \star}\end{array}$ & $\begin{array}{l}-0.8124 \\
(-3.55)^{\star \star \star}\end{array}$ \\
\hline EMPG & $\begin{array}{l}0.0046 \\
(0.37)\end{array}$ & $\begin{array}{l}0.0045 \\
(0.36)\end{array}$ & $\begin{array}{l}0.0045 \\
(0.36)\end{array}$ & $\begin{array}{l}0.0103 \\
(0.96)\end{array}$ \\
\hline DERIV & & $\begin{array}{c}0.0023 \\
(2.83)^{\star \star \star}\end{array}$ & & $\begin{array}{l}0.0022 \\
(2.05)^{\star \star}\end{array}$ \\
\hline SWAPS & & & $\begin{array}{l}0.0012 \\
(1.30)\end{array}$ & \\
\hline OPTIONS & & & $\begin{array}{c}0.0028 \\
(2.90)^{\star \star \star}\end{array}$ & \\
\hline FUTURES & & & $\begin{array}{c}0.0119 \\
(2.04)^{* \star}\end{array}$ & \\
\hline FORWARDS & & & $\begin{array}{c}0.0021 \\
(1.90)^{* \star}\end{array}$ & \\
\hline $\mathrm{OF}$ & & & $\begin{array}{l}-0.0201 \\
(-1.68)^{*}\end{array}$ & \\
\hline OS & & & $\begin{array}{l}-0.0011 \\
(-0.62)\end{array}$ & \\
\hline OW & & & $\begin{array}{l}-0.0002 \\
(-0.09)\end{array}$ & \\
\hline FS & & & $\begin{array}{c}0.0087 \\
(-1.32)\end{array}$ & \\
\hline FW & & & $\begin{array}{l}-0.0020 \\
(-0.26)\end{array}$ & \\
\hline SW & & & $\begin{array}{c}-0.0023 \\
(-0.86)\end{array}$ & \\
\hline OFS & & & $\begin{array}{l}0.0188 \\
(1.41)\end{array}$ & \\
\hline OFW & & & $\begin{array}{l}0.0087 \\
(0.43)\end{array}$ & \\
\hline FSW & & & $\begin{array}{l}0.0082 \\
(0.74)\end{array}$ & \\
\hline SWO & & & $\begin{array}{l}0.0011 \\
(0.30)\end{array}$ & \\
\hline OFSW & & & $\begin{array}{l}-0.0163 \\
(-0.73)\end{array}$ & \\
\hline DEALER & & & & $\begin{array}{l}-0.0081 \\
(-3.54)^{\star \star \star}\end{array}$ \\
\hline FOREIGN & & & & $\begin{array}{l}-0.0059 \\
(-3.11)^{\star \star \star}\end{array}$ \\
\hline LAGGED CILGA & & & & $\begin{array}{l}0.0054 \\
(1.41)\end{array}$ \\
\hline UNLC & & & & $\begin{array}{c}0.0466 \\
(4.07)^{\star \star \star}\end{array}$ \\
\hline OBSERVATIONS & 232096 & 232096 & 232096 & 223881 \\
\hline ADJ R-SQUARE & 0.00566 & 0.00416 & 0.00424 & 0.00573 \\
\hline
\end{tabular}

\footnotetext{
${ }^{a}$ All regression equations contain time-period indicator variables. T-statistics (reported in parentheses) are calculated using Newey-West heteroscedasticity-and-autocorrelation-consistent errors. Statistical significance is displayed by the use of one ( $10 \%)$, two (5\%), or three $(1 \%)$ stars. The sample contains 36 quarters of observations from 1996 Q1 through 2004 Q4. The dependent variable for all regressions is the quarterly change in C\&I loans relative to last period's total assets.

${ }^{\mathrm{b}}$ CARATIO is measured as the ratio of total equity capital to total assets at time t-1. CILCOFA is measured as the ratio of C\&I loan chargeoffs in period t -1 to total assets in period $\mathrm{t}-1$. EMPG is the state employment growth rate, where EMP equals the total employment in the state in which the bank's headquarters are located. DERIV, SWAPS, OPTIONS, FORWARDS, and FUTURES are instrumental variables obtained from a probit specification for participation in the indicated derivative markets. OF, OS, OW, FS, FW, SW, OFS, OFW, FSW, SWO, and OFSW are eleven possible interactions between each type of derivative instruments. Among these interaction terms, $\mathrm{O}$ stands for option, $\mathrm{F}$ stands for futures, $\mathrm{S}$ stands for swaps, and $\mathrm{W}$ stands for forwards. DEALER is a binary variable, which equals to one if the institution is listed as an IDSA member, or zero otherwise. FOREIGN is a binary variable, which equals to one if the institution is a foreign-owned institution, or zero otherwise. LAGGED CILGA is the first lag of the dependent variable. UNLC is unused lines of credit to total assets.
}

Regression (2) of Table 4 shows that banks using any type of interest-rate derivative, on average, experience significantly higher growth in their C\&I loan portfolios. This positive relationship between derivatives use and C\&I 
loan growth is consistent with Diamond's (1984) model of financial intermediation. In that model, Diamond argues that interest-rate derivatives allow commercial banks to lessen their systematic exposure to changes in interest rates. In addition, interest-rate derivatives create extra risk tolerance, enabling banks to provide more C\&I loans without increasing the total risk level faced by the banks. Furthermore, a positive and significant coefficient estimate on the DERIV variable indicates that the net effect of derivative use on C\&I lending activity is complementary. That is, the complementary effect dominates any substitution effect.

The regression reported in column (3) of Table 4 examines the relative role played by each type of derivative instrument in explaining C\&I loan growth. Since banks that invest in the human capital and internal control systems necessary to be active in the market for derivatives are more likely to use more than one type of derivative, we also control for the effect of eleven possible interactions between each type of derivative activity in the regression. See Table 4 for a detailed breakdown of interaction terms. The results show that the coefficient estimates on all four kinds of derivative variables are positive. The coefficient estimates on OPTIONS, FORWARDS, and FUTURES are statistically significant. These results suggest that the use of these three types (Options, Forwards, and Futures) of derivatives is significantly associated with higher C\&I loan growth. Further, except for the interaction between options and futures, none of the coefficient estimates on the interaction terms between each type of derivative activity is significant. Without the interaction terms, the coefficient estimates (not reported) on all four kinds of derivative instruments have a positive sign, and the estimates on options and forwards are statistically significant.

Overall, our results suggest that aggregate use of derivative instruments, in particular interest-rate options, interest-rate futures, and interest-rate forwards, is associated with higher growth rates in C\&I loans.

\section{Robustness Check}

To check the validity of the regression results, we augment the regression (2) specification by adding variables measuring other characteristics of financial institutions that may explain lending activity during the sample period. The augmented regression reported in column (4) of Table 4 addresses the concern of omitting important variables that might alter the observed positive relationship between lending activity and participation in interest-rate derivatives.

First, the lagged dependent variable (LAGGED CILGA) is included in the regression to account for the possibility that the derivative-participation variable is a proxy for growth potential. we also include a control for a foreign-firm effect by introducing a binary variable equal to one if a bank is a subsidiary of a foreign financial institution (FOREIGN), or zero otherwise. Previous literature suggests that the operation of foreign-owned banks helps to fund U.S. operations of foreign industrial firms. Therefore, foreign-owned banks may be expected to provide both loans and interest-rate derivatives to their customers, inducing a positive coefficient. On the other hand, foreign-owned banks also have some disadvantages due to problems in managing from a distance and coping with multiple economic/regulatory environment. For example, see Berger, Dai, Ongena, and Smith (2003) and Buch (2003).These disadvantages may cause foreign-owned banks to experience slower growth in their loan portfolios, other things being equal.

In consideration of the possibility of a spurious relationship between C\&I loan growth and dealer activity performed by large banks that are heavily involved in derivative contracting, a binary variable is included in the regression to control for membership in the International Swaps and Derivatives Association (ISDA). The binary variable DEALER equals one if a bank is identified as a dealer by the ISDA membership list or zero otherwise.

Finally, the ratio of the dollar value of any unused lines of credit (UNLC) to total assets is included as a measure of risk tolerance. The risk is two-dimensional. First, liquidity problems may emerge as banks commit to fill larger credit lines. Second, banks' off-balance-sheet exposures to credit risk may increase as they extend lines of credit to manage the interest-rate risk. Controls introduced for these possibilities provide a way of separating loan growth from risk-taking motivations.

Regression (4) incorporates the above proxies for other activities that may cloud the positive association between derivative activity and loan growth. As shown in column (4) of Table 4, the results of the study remain robust. Specifically, the coefficient on predicted derivative activity (DERIV) remains positive and statistically significant. In addition, the coefficient on the foreign-bank variable (FOREIGN) is negative and highly significant, suggesting that foreign-owned banks experience slower growth in C\&I loan lending activities. As Brewer, Minton, and Moser (2000) suggest, dealer activities performed by the banks could give rise to a negative relationship between derivative usage and lending because banks enhance their revenue by acting as over-the-counter (OTC) dealers and charge a fee for placing derivative positions. Consistent with their prediction, the coefficient on the dealer variable is negative and 
significant. Finally, the coefficient estimate on the lagged dependent variable is not significantly different from zero. The ratio of unused lines of credit to total assets, UNLC, is positive and significant, suggesting that the higher the risk tolerance as measured by UNLC, the greater the C\&I loan growth.

\section{Conclusions}

Commercial banks employ different methods, including the use of interest-rate derivatives to manage interest-rate risks. The use of these derivative instruments by banks has increased tremendously rising from notional amounts of $\$ 27.88$ trillion at the end of December of 1996 to $\$ 62.78$ trillion at the end of 2004 . The relationship between derivative usage and lending activity has been studied in related literature. This paper addresses the question of whether derivative usage complements or substitutes for the lending activity, investigates the relationship between bank participation in derivative contracting and bank lending for the period of March 31, 1996, through December 31, 2004.

Overall, this study documents a direct relationship between derivative usage by U.S. banks and growth in their commercial and industrial loan portfolios for the sample period of 1996 to 2004. More specifically, we find that aggregate use of derivative instruments, in particular interest-rate options, interest-rate futures, and interest-rate forwards, is associated with higher growth rates in C\&I loans. These findings are consistent with the results of an earlier study by Brewer, Minton, and Moser (2000), who examine the relationship between lending and derivative usage for a sample of FDIC-insured commercial banks between 1985 and 1992. This documented positive association is consistent with Diamond's (1984) hypothesis that derivative contracting and lending are complementary activities. Diamond's model predicts that banks can reduce the cost of delegated monitoring by holding a diversified portfolio. These results suggest that C\&I loan growth has a significant positive relationship with the capital ratio. These results are consistent with the previous banking research in that banks with stronger capital are more able to increase their loan portfolios. We also document a negative relationship between C\&I loan charge-offs and C\&I loan growth. This negative association is in line with the notion that the charge-offs variable captures the impact of regulatory pressures or a strong economic environment, or both. Further, the main results are confirmed after a robustness check.

Finally, the sample shows that less than 3 percent of the sample banks report having open positions in all four kinds of interest-rate derivative instruments. In contrast, nearly half of the banks with total assets greater than $\$ 10$ billion report having positions in all four kinds of interest-rate derivative instruments. This result strongly suggests that large banking organizations are much more likely than small banking organizations to fully utilize derivatives.

\section{References}

Beatty, A., \& Gron, A. (2001). Capital, portfolio, and growth: Bank behavior under risk-based capital guidelines. Journal of Financial Services Research, 20, 5-31. https://doi.org/10.1023/A:1011146725028

Berger, A. N., Dai, Q., Ongena, S., \& Smith, D. C. (2003). To what extent will the banking industry be globalized? A study of bank nationality and reach in 20 European nations. Journal of Banking and Finance, 27, 383-415. https://doi.org/10.1016/S0378-4266(02)00386-2

Bernanke, B., \& Lown, C. (1991). The credit crunch. Brookings Papers on Economic Activity, (2), 205-247. https://doi.org/10.2307/2534592

Bhattacharaya, J. (1993). The role of foreign banks in developing countries: A survey of evidence. Mimeograph, Cornell University.

Brewer III, E., Jackson III, W. E., \& Moser, J. T. (1996). Alligators in the swap, Journal of Money, Credit and Banking, 28, 482-502.

Brewer III, E., Jackson III, W. E., \& Moser, J. T. (2001). The value of using interest rate derivatives to manage risk at U.S. banking organizations. Economic Perspectives, (3), 49-66.

Brewer III, E., Minton, B. A., \& Moser, J. T. (2000). Interest-rate derivatives and bank lending. Journal of Banking \& Finance, 24(3), 353-379. https://doi.org/10.1016/S0378-4266(99)00041-2

Buch, C. M. (2003). Information or regulation: what drives the international activities of commercial banks? Journal of Money, Credit \& Banking, (6), 851-869. https://doi.org/10.1353/mcb.2003.0042

Carter, D. A., \& Sinkey, J. F. (1998). The Use of Interest Rate Derivatives by End-users: The Case of Large Community Banks. Journal of Financial Services Research, (1), 17-34. https://doi.org/10.1023/A:1008057418368 
Diamond, D. W. (1984). Financial Intermediation and Delegated Monitoring. Review of Economic Studies, 51(3), 393-414. https://doi.org/10.2307/2297430

Kim, S., \& Koppenhaver, G. D. (1992). An empirical analysis of bank interest rate swaps. Journal of Financial Services Research, 7, 57-72. https://doi.org/10.1007/BF01048340

Minton, B., Stulz, R. M., \& Williamson, R. (2005). How Much Do Banks Use Credit Derivatives to Reduce Risk? NBER Working Papers, 1.

Purnanandam, A. (2007). Interest rate derivatives at commercial banks: An empirical investigation. Journal of Monetary Economics, 54(6), 1769-1808. https://doi.org/10.1016/j.jmoneco.2006.07.009

Schrand, C. M. (1997). The Association between Stock-Price Interest Rate Sensitivity and Disclosures about Derivative Instruments. The Accounting Review, (1), 87-109.

Sharpe, S. A. (1995). Bank capitalization, regulation, and the credit crunch: A critical review of the research findings, Finance and Economics Discussion Series Paper, No. 95/20, Board of Governors of the Federal Reserve System.

Sharpe, S. A., \& Acharya, S. (1992). Loan losses, bank capital, and the credit crunch, Working Paper, Federal Reserve Board of Governors, Washington, DC.

Sinkey, J. F., \& Carter, D. A. (1994). The derivatives activities of U.S. commercial banks. Papers and Proceedings of the 30th Annual Conference on Bank Structure and Regulation, 165-185.

Williams-Stanton, S. (1996). The effects of risk-based capital on wealth and risk-taking in banking. Working paper, Ohio State University.

Appendix A. First-stage estimation of probability of derivative usage ${ }^{a, b}$

\begin{tabular}{lcc}
\hline Variable & Mean Estimates & Standard Error \\
\hline INTERCEPT & -5.4338 & 0.30143 \\
OPPRF & -6.6702 & 3.7844 \\
CARATIO & 1.4606 & 0.2315 \\
LNTOTASST & 0.2958 & 0.0446 \\
LAGDEPENDENT & 3.4807 & 0.1187 \\
OBSERVATIONS & & 232096 \\
\hline PSEUDO R-SQUARE & 232096 & \\
\hline
\end{tabular}

${ }^{a}$ The probit specification is estimated for each quarter for 36 quarters from 1996 Q1 through 2004 Q4. The mean estimates and the standard error are the mean and the standard error of 36 coefficient estimates.

${ }^{\mathrm{b}}$ The dependent variable for the first-stage regression is the probability of derivative usage. OPPRF is the sample banks' net interest margin. CARATIO is the sample banks' capital-to-asset ratio. LNTOTASST is the logarithm of the sample banks' total assets, and LAGDEPENDENT is the first lag of the dependent variable. 
Appendix B. Coefficient estimates on time dummy variable for each regression over the period from March 1996 to December 2004

\begin{tabular}{|c|c|c|c|c|}
\hline $\begin{array}{l}\text { Independent } \\
\text { variables }\end{array}$ & Regression (1) & Regression (2) & Regression (3) & Regression (4) \\
\hline Intercept & $\begin{array}{c}-0.00521 \\
(-3.95)^{* * *}\end{array}$ & $\begin{array}{l}-0.0054 \\
(-1.72)^{*}\end{array}$ & $\begin{array}{l}-0.0054 \\
(-1.73)^{*}\end{array}$ & $\begin{array}{l}-0.0055 \\
(-1.49)\end{array}$ \\
\hline D2 (1996Q3) & $\begin{array}{c}-0.0075 \\
(-5.67)^{* * *}\end{array}$ & $\begin{array}{c}-0.0023 \\
(-2.73)^{* * *}\end{array}$ & $\begin{array}{c}-0.0023 \\
(-2.74)^{* * *}\end{array}$ & $\begin{array}{c}0.0027 \\
(1.91)^{* *}\end{array}$ \\
\hline D3 (1996Q4) & $\begin{array}{l}-0.0048 \\
(-3.60)^{* * *}\end{array}$ & $\begin{array}{l}0.0004 \\
(0.27)\end{array}$ & $\begin{array}{l}0.0004 \\
(0.28)\end{array}$ & $\begin{array}{c}0.0016 \\
(3.85)^{* * *}\end{array}$ \\
\hline D4 (1997Q1) & $\begin{array}{c}-0.0059 \\
(-4.47)^{* * *}\end{array}$ & $\begin{array}{l}-0.0007 \\
(-0.87)\end{array}$ & $\begin{array}{l}-0.0007 \\
(-0.87)\end{array}$ & $\begin{array}{c}0.0022 \\
(4.60)^{* * *}\end{array}$ \\
\hline D5 (1997Q2) & $\begin{array}{c}-0.0054 \\
(-4.05)^{* * *}\end{array}$ & $\begin{array}{l}-0.0002 \\
(-0.24)\end{array}$ & $\begin{array}{l}-0.0002 \\
(-0.24)\end{array}$ & $\begin{array}{l}-0.0002 \\
(-0.38)\end{array}$ \\
\hline D6 (1997Q3) & $\begin{array}{c}-0.0079 \\
(-5.90)^{* * *}\end{array}$ & $\begin{array}{c}-0.0027 \\
(-2.84)^{* * *}\end{array}$ & $\begin{array}{c}-0.0027 \\
(-2.84)^{* * *}\end{array}$ & $\begin{array}{c}0.0014 \\
(2.99)^{* * *}\end{array}$ \\
\hline D7 (1997Q4) & $\begin{array}{c}-0.0063 \\
(-4.64)^{* * *}\end{array}$ & $\begin{array}{l}-0.001 \\
(-1.24)\end{array}$ & $\begin{array}{l}-0.0011 \\
(-1.26)\end{array}$ & $\begin{array}{l}0.0071 \\
(1.18)\end{array}$ \\
\hline D8 (1998Q1) & $\begin{array}{l}-0.0004 \\
(-0.27)\end{array}$ & $\begin{array}{l}0.0048 \\
(0.80)\end{array}$ & $\begin{array}{l}0.0048 \\
(0.80)\end{array}$ & $\begin{array}{c}0.0013 \\
(3.15)^{* * *}\end{array}$ \\
\hline D9 (1998Q2) & $\begin{array}{c}-0.0064 \\
(-4.72)^{* * *}\end{array}$ & $\begin{array}{l}-0.0012 \\
(-1.43)\end{array}$ & $\begin{array}{l}-0.0012 \\
(-1.43)\end{array}$ & $\begin{array}{l}-0.0006 \\
(-1.37)\end{array}$ \\
\hline D10 (1998Q3) & $\begin{array}{l}-0.0084 \\
(-6.18)^{* * *}\end{array}$ & $\begin{array}{c}-0.0032 \\
(-3.62)^{* * *}\end{array}$ & $\begin{array}{c}-0.0032 \\
(-3.63)^{* * *}\end{array}$ & $\begin{array}{c}0.0012 \\
(2.30)^{* *}\end{array}$ \\
\hline D11 (1998Q4) & $\begin{array}{l}-0.0084 \\
(-6.18)^{* * *}\end{array}$ & $\begin{array}{l}-0.0011 \\
(-1.26)\end{array}$ & $\begin{array}{l}-0.0011 \\
(-1.27)\end{array}$ & $\begin{array}{c}0.0013 \\
(3.04)^{* * *}\end{array}$ \\
\hline D12 (1999Q1) & $\begin{array}{c}-0.0063 \\
(-4.58)^{* * *}\end{array}$ & $\begin{array}{l}-0.001 \\
(-1.13)\end{array}$ & $\begin{array}{l}-0.001 \\
(-1.13)\end{array}$ & $\begin{array}{c}0.0020 \\
(2.47)^{* *}\end{array}$ \\
\hline D13 (1999Q2) & $\begin{array}{c}-0.0062 \\
(-4.55)^{* * *}\end{array}$ & $\begin{array}{l}-0.0005 \\
(-0.51)\end{array}$ & $\begin{array}{l}-0.0006 \\
(-0.55)\end{array}$ & $\begin{array}{l}0.0004 \\
(0.49)\end{array}$ \\
\hline D14 (1999Q3) & $\begin{array}{l}-0.0051 \\
(-1.50)\end{array}$ & $\begin{array}{l}-0.0021 \\
(-1.86)^{*}\end{array}$ & $\begin{array}{l}-0.0021 \\
(-1.86)^{*}\end{array}$ & $\begin{array}{c}0.0028 \\
(4.25)^{* * *}\end{array}$ \\
\hline D15 (1999Q4) & $\begin{array}{l}-0.0067 \\
(-1.94)^{*}\end{array}$ & $\begin{array}{l}0.0007 \\
(0.70)\end{array}$ & $\begin{array}{l}0.0007 \\
(0.62)\end{array}$ & $\begin{array}{c}0.0057 \\
(4.12)^{* * *}\end{array}$ \\
\hline D16 (2000Q1) & $\begin{array}{l}-0.0039 \\
(-1.14)\end{array}$ & $\begin{array}{c}0.0033 \\
(2.07)^{* *}\end{array}$ & $\begin{array}{c}0.0032 \\
(2.03)^{* *}\end{array}$ & $\begin{array}{c}0.0026 \\
(6.15)^{* * *}\end{array}$ \\
\hline D17 (2000Q2) & $\begin{array}{l}-0.0014 \\
(-0.41)\end{array}$ & $\begin{array}{l}0.0002 \\
(0.32)\end{array}$ & $\begin{array}{l}0.0003 \\
(0.33)\end{array}$ & $\begin{array}{l}0.0004 \\
(0.98)\end{array}$ \\
\hline D18 (2000Q3) & $\begin{array}{l}-0.0049 \\
(-3.61)^{* * *}\end{array}$ & $\begin{array}{l}-0.0014 \\
(-1.51)\end{array}$ & $\begin{array}{l}-0.0014 \\
(-1.51)\end{array}$ & $\begin{array}{l}0.0059 \\
(1.54)\end{array}$ \\
\hline D19 (2000Q4) & -0.0067 & 0.0035 & 0.0035 & 0.0010 \\
\hline
\end{tabular}




\begin{tabular}{|c|c|c|c|c|}
\hline & $(-4.81)^{* * *}$ & $(0.90)$ & $(0.90)$ & $(1.50)$ \\
\hline \multirow[t]{2}{*}{ D20 (2001Q1) } & -0.0017 & -0.0011 & -0.0011 & 0.0016 \\
\hline & $(-1.25)$ & $(-1.06)$ & $(-1.04)$ & $(2.54)^{* *}$ \\
\hline \multirow[t]{2}{*}{ D21 (2001Q2) } & -0.0063 & -0.0009 & -0.0009 & -0.0012 \\
\hline & $(-4.52)^{* * *}$ & $(-1.05)$ & $(-1.05)$ & $(-2.07)^{* *}$ \\
\hline \multirow[t]{2}{*}{ D22 (2001Q3) } & -0.0062 & -0.0039 & -0.0038 & -0.0001 \\
\hline & $(-4.84)^{* * *}$ & $(-4.07)^{* * *}$ & $(-4.07)^{* * *}$ & $(-0.15)$ \\
\hline \multirow[t]{2}{*}{ D23 (2001Q4) } & -0.0091 & -0.0024 & -0.0024 & 0.0006 \\
\hline & $(-7.14)^{* * *}$ & $(-2.29)$ & $(-2.29)^{* *}$ & $(0.49)$ \\
\hline \multirow[t]{2}{*}{ D24 (2002Q1) } & -0.0077 & -0.0017 & -0.0017 & 0.0007 \\
\hline & $(-5.95)^{* * *}$ & $(-1.14)$ & $(-1.13)$ & $(1.28)$ \\
\hline \multirow[t]{2}{*}{ D25 (2002Q2) } & -0.0069 & -0.0019 & -0.0019 & -0.0014 \\
\hline & $(-5.35)^{* * *}$ & $(-2.16)^{* *}$ & $(-2.15)^{* *}$ & $(-2.37)^{* *}$ \\
\hline \multirow[t]{2}{*}{ D26 (2002Q3) } & -0.0072 & -0.0040 & -0.0040 & -0.0002 \\
\hline & $(-5.59)^{* * *}$ & $(-4.35)^{* * *}$ & $(-4.34)^{* * *}$ & $(-0.04)$ \\
\hline \multirow[t]{2}{*}{ D27 (2002Q4) } & -0.0093 & -0.0026 & -0.0026 & 0.0003 \\
\hline & $(-7.18)^{* * *}$ & $(-2.75)^{* *}$ & $(-2.73)^{* *-}$ & $(0.54)$ \\
\hline \multirow[t]{2}{*}{ D28 (2003Q1) } & -0.0079 & -0.0022 & -0.0022 & -0.0007 \\
\hline & $(-6.07)^{* * *}$ & $(-2.10)^{* *}$ & $(-2.07)^{* *}$ & $(-1.35)$ \\
\hline \multirow[t]{2}{*}{ D29 (2003Q2) } & -0.0074 & -0.0032 & -0.0032 & -0.0022 \\
\hline & $(-5.66)^{* * *}$ & $(-3.57)^{* * *}$ & $(-3.55)^{* * *}$ & $(-3.78)^{* * *}$ \\
\hline \multirow[t]{2}{*}{ D30 (2003Q3) } & -0.0085 & -0.0048 & -0.0048 & 0.0001 \\
\hline & $(-6.53)^{* * *}$ & $(-5.27)^{* * *}$ & $(-5.24)^{* * *}$ & $(0.19)$ \\
\hline \multirow[t]{2}{*}{ D31 (2003Q4) } & -0.010 & -0.0023 & -0.0023 & 0.0004 \\
\hline & $(-7.74)^{* * *}$ & $(-2.47)^{* *}$ & $(-2.44)^{* * *}$ & $(0.55)$ \\
\hline \multirow[t]{2}{*}{ D32 (2004Q1) } & -0.0076 & -0.0022 & -0.0021 & 0.0002 \\
\hline & $(-5.78)^{* * *}$ & $(-2.14)^{* *}$ & $(-2.11)^{* * *}$ & $(0.35)$ \\
\hline \multirow[t]{2}{*}{ D33 (2004Q2) } & -0.0074 & -0.0022 & -0.0022 & -0.0008 \\
\hline & $(-5.60)^{* * *}$ & $(-2.31)^{* *}$ & $(-2.28)^{* * *}$ & $(-1.48)$ \\
\hline \multirow[t]{2}{*}{ D34 (2004Q3) } & -0.0074 & -0.0034 & -0.0034 & 0.0001 \\
\hline & $(-5.64)^{* * *}$ & $(-3.83)^{* * *}$ & $(-3.79)^{* * *}$ & $(0.23)$ \\
\hline \multirow[t]{2}{*}{ D35 (2004Q4) } & -0.0086 & -0.0024 & -0.0024 & $(0.079)$ \\
\hline & $(-6.58)^{* * *}$ & $(-2.53)^{* *}$ & $(-2.49)^{* *}$ & $(2.16)^{* *}$ \\
\hline
\end{tabular}

